\title{
Corporate Banking: Analysis, Valuation and Financing Structure of the Company
}

\author{
Daria Grebenkova
}

International Finance Faculty, Department of World Economy and World Finance, Financial University, Moscow, Russia

\begin{abstract}
Today, during the period of ongoing changes in the financial market, banks face the challenges of cost reduction, revision of the product line and more explicit customer segmentation. In the environment, corporate clients are also observed significant changes: there is a rotation of personnel change the development strategies of companies that entails new requirements for banking products. Can banks quickly adapt to new market conditions and optimize work with corporate clients using existing technologies and information systems? Besides, that will help improve growth. Corporate sales of banking products in the current conditions? These questions the author tries to answer in her paper.

Keywords: corporate banking; banking products; bank's strategic goals; corporate customers of banking services JEL Classification: G21

(C) Daria Grebenkova, 2020
\end{abstract}

\section{Introduction}

The unfavorable conditions in the world capital markets and the tightening of banking legislation in Europe inevitably lead to a narrowing of the scale of Bank credit operations. Many analysts of the banking market predict an increase in the share of institutional investors in the total volume of investment financing, especially when it comes to infrastructure facilities. At the same time, banks remain the main suppliers of borrowed funds in the field of investment and project financing. Despite the fact that for banks and borrower's investment financing remains clear, reliable and promising product, many lenders are experiencing difficulties with liquidity in the medium and long term and therefore avoid participation in the financing of long-term projects. In addition, the tightening of banking legislation and the introduction of Basel II/III standards do not allow us to expect that the system-forming banks will soften their demands on the quality of the loan portfolio and will pursue a more aggressive lending policy.

Moreover, purposeful capital investment creates production and jobs, fills the state budget with tax payments and allows, in general, im- proving the life of the country. You can see the impact of investment in the economy through macroeconomic indicators such as GDP, unemployment, inflation, the Central Bank's key rate and other indicators.

One of the important condition of capital investment is its expediency and validity, as well as the form of investment that will best meet the interests of investors, intermediaries and resource owners. Today, to involve the diverted capital in business, use two ways of financing - debt and equity.

Debt financing in comparison with equity has a number of advantages as a form of capital investment: the emergence of a tax shield, the preservation of control in the company by the owners, the exact maturity of the debt, the order of payments in the event of bankruptcy. Although it is worth noting, the choice of debt financing is always considered based on the planned objectives of the project and the expectations of the parties involved in the transaction.

On the example of the implemented project in the field of construction and management of commercial real estate in Nizhny Novgorod, an analytical procedure will be given for the prepa- 
ration of the conclusion of the feasibility of debt financing in the form of a Bank loan for a number of purposes, including reconstruction, modernization of the shopping and entertainment center (hereinafter the Mall), financing of current activities and refinancing of debt to another Bank.

The author studied the theoretical aspects of some instruments of debt financing of investment projects and to analyze the creditworthiness of a potential borrower for PJSC Bank VTB based on the developed financial model and structured financial covenants.

The subject of the study is the retrospective cash flows of companies included in the consolidation perimeter in accordance with the rules of PJSC Bank VTB, and the projected cash flows of the investment project of the Lotus Plaza. Data analysis was carried out by means of such research methods as induction and deduction, modeling and measurement, comparison and analysis of documents.

\section{Bottlenecks of Financing Design and Operating Management of Funding Programs}

\section{The main conditions for financing investment projects}

Group of companies A'bel is a reliable client, whose main activity relates to the construction of commercial and residential real estate in Nizhny Novgorod since 2000, as well as to the management of some of the group's properties. During the last five years of its cooperation with the Bank, the client has not had any overdue obligations, and the credit rating is estimated as $\mathrm{B}++$, i.e. the probability of timely fulfilment of the Client's current obligations to the credit institution is estimated as moderate. The probability of financial difficulties in case of urgent obligations is estimated as high. Repayment of liabilities is highly dependent on the stability of macroeconomic and market indicators as the main activity is related to the construction and management of the real estate. In the market, the client holds a share of $20-25 \%$ according to the estimates of the leading marketing Agency CBRE. The total number of objects on the territory of Nizhny Novgorod is about 25 buildings for commercial and residential purposes.
The strategy of the group is the construction of the high-quality real estate. Recently, the Group operates on the territories of promising and undeveloped areas of the city. Reasonable prices, infrastructure support, accounting for innovations and market dynamics forecast allow the company to attract high-quality tenants to fill retail space and ensure the rapid sale of other areas. Shopping centre Lotus Plaza is a modern, high-quality entertainment centre of new generation with already large and well-established tenants: IKEA, M. Video, ZARA, Marks \& Spencer, Sportmaster, other netizens and grocery hypermarket Lenta. The total area of the shopping centre of 28,000 sq. $\mathrm{m}$ and $25 \mathrm{sq} . \mathrm{m}-$ lettable area.

Let us consider in more detail the non-financial environment of the project, namely a brief description of the investment project, the characteristics of the market situation and the expected risks of the Client.

To assess the attractiveness of the project, will help the marketing analysis of the industry and the prospects for its development, the forecast period, which best corresponds to the maturity of new debt.

The commercial real estate market in Russia is in a satisfactory state with clear prospects for development and diversification into more indepth segments. The whole past year (2016) will be remembered for the gradual stabilization of the market, increased business activity of "players" and investors. Of course, new projects practically did not enter the market, the investor did not attract investment in the construction of sites for large centres, but the funds were allocated for the modernization of the areas, their increase and equipping with new spaces for social and recreational purposes for all categories of citizens.

It is assumed that a small boost in economic growth according to the Ministry of Finance of the Russian Federation at the level of $0.8 \%-2 \%$ in 2018 from the second half of the year will start a new cycle in the field of commercial real estate. Against the background of such expectations, the investor can consider the feasibility of investing in objects of this type and expect a good return potential on invested capital.

Note that for the start of new projects, the reduction of the key rate of the Central Bank of Russia does not allow to start working with development projects from scratch. The draft civil code has been 
built not so long ago (2014). Therefore, there is no need for consideration and selection of construction sites, coordination of the technical and economic plan of the whole object and other documentation with a high time-consuming preparation.

These factors are a significant advantage for lending to the project by the Bank because there is an opportunity to win on the market and get another part of the market in the region.

Today, commercial real estate is divided into commercial, office and warehouse. The market of trade and entertainment sector is quite mastered in its usual sense. However, the inertia of the market does not reduce turnover compared to office real estate. In terms of investment, retail properties received $18 \%$ of $\$ 300$ billion, according to CBRE. Thus, it is impossible to talk about the braking of the industry and its stagnation, but the most interesting factor for an already operating object is not the macroeconomic prerequisites, but the internal details of the industry: rates, security, quality of tenants, occupancy and so on.

As a rule, the commercial real estate industry significantly depends on the region in question. In each region, there is always a leader and a leading player who has the maximum location, a strong pool of tenants and occupancy significantly close to $100 \%$. However, the average figures change the picture, allowing you to look more soberly at the situation.

The average provision in the regions is significantly different, but significantly, average, excluding Moscow, Saint Petersburg, is 200 sq. $\mathrm{m}$. per thousand residents. The total area of quality space is around 1.2 million square meters, of which the increase over the past year amounted to 719 thousand sq. m. Average rental rates definitely went in the ruble zone as a fixed share or a percentage of turnover, and the average vacancy rate is $7-8 \%$ in Metropolitan cities. Regions are gaining momentum - Kursk, Arkhangelsk, Vladivostok, Khabarovsk, Stavropol and some others. Nizhny Novgorod is already sufficiently equipped with high-quality retail space. However, it still does not occupy a place in the top three and is about 5-7 place along with cities such as Samara, Krasnodar others.

The current situation in the Nizhny Novgorod market is gradually stabilizing and comes to life in terms of the interest of tenants both new and experienced in this regional market to develop new areas and/or adhere to the expansion strategy. It can be noted that in the mood of the tenants there is already a desire to sign long-term contracts, the term of which will be from 3 to 5 years - is about $25 \%$ and $35 \%$ - are ready for even longer contracts, but with floating conditions. This is a positive wave because there is a stabilizing factor both the tenant and the rate, which increasingly meets the economic realities of the Russian economy and take into account seasonality, crisis experiences, growth and stagnation of the business and allows, of course, to fix the minimum required part for the tenant income. Rates of average prices are relatively dynamic, racing is not comparable with the abrupt deviations of a year of crisis, and it is acceptable for the market of the region (Fig. 1).

The comparative dynamics of rental rates in the districts of the city explains the relative decline in the market of the trading segment as a whole, as some areas, for example, Leninsky and Moskovsky show good growth. The Autozavodsky part of the city was distinguished by a decrease in rates -1.3 , which is not an emergency drop, it is possible that in this area there is a revision of contracts or a revision of the terms of calculation of rental rates for tenants of commercial premises. Analysts expect the stabilization of prices for rented premises in the "lagging" areas to date + $0.8 \%$ (Table 1 ).

The city provided quality retail space to a sufficient degree -619 sq. m./thousand people ahead of Nizhniy Novgorod Ekaterinburg only with indicators of 624 sq. m./thousand people. At the regional division shows a uniform distribution of the proposal except for the Nizhniy Novgorod area (Fig. 2). The quality and equipment of shopping and entertainment centres in the city are characterized as high-class and modern facilities of a new type. Only in some areas, there are centres that can be attributed to the old class, the year of construction of which ranges from 2000 until 2008.

Avtozavodskiy district of Nizhniy Novgorod is situated in Zarechnaya part of the city and covers an area of 9.4 thousand ha. Area economically and culturally isolated saturated. The project under consideration is located in the Central part of the area. The population of the district as of 01.01 .2016 is 300,436 people. The average salary in the city is at the level of 26,000 roubles. The overall economic picture of the region has been improving since January 2017 after a sharp fall of 


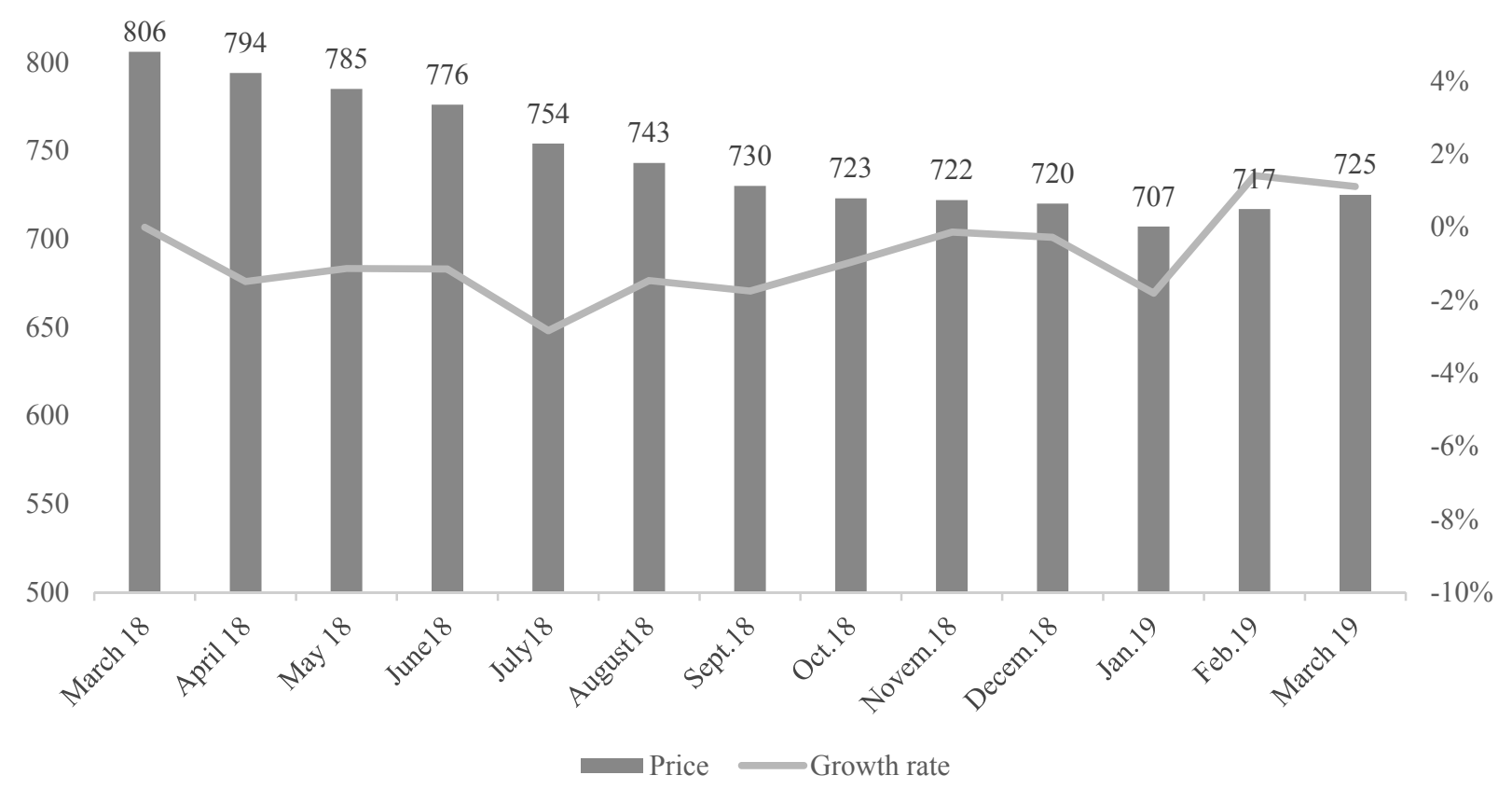

Figure 1. Dynamics of the average price in the market of rent of trade premises

Source: The author.

the main macro indicators of the region in 2015 by $15-20 \%$.

Analysis of the competitive environment (Table 2) shows that the GC has chosen the right strategy, i.e. expansion of the shopping Mall and its addition to the new socio-cultural and entertainment space. After all, the main successful competitors have a large area and as a result, attract more customers with a significant pastime on site.

The initial request for credit funds assumed conditions (table 3), going slightly against the Bank's assessment. Thus, the initial investment initially specified for 1.5 billion rubles, reduced to 1.2 billion rubles. The feasibility of changing the amount of the investment program of the loan agreement with the client will be set out below based on the assessment of the financial activities of the borrower, the financial model and its stress.

Description of the client, the marketing industry, the strategy of the management company in relation to the development and expansion of the Mall is clean, logical and interrelated. The industry seems to be quite a promising market for deepening its directions and modernization in the near future. Working with a reliable and experienced client allows you to minimize risks and anticipate the most likely of them. Expert opinion of marketers only confirms the possibility of implementing new but well-developed projects. From the point of view of the non-financial basis of the project, it is possible to emphasize its realism, conceptuality and validity.

\section{Diagnosis of a Business Model in the Process of Financial Analysis}

Consolidation of the group carried out by the method of proportional consolidation of indicators of all 6 companies included in the analysis, allowed to conduct a full assessment of the balance sheet and the report on financial results. The group of companies analyzed to determine the amount of credit for the SPV company includes about 20 companies. Significant organizations, whose share in the authorized capital exceeds the parameters set by the Bank for mutual participation in the capital, are the previously mentioned six companies, which are included in the credit analysis perimeter. The main stages of the analysis were identified coefficient and settlement-analytical with a brief conclusion on the key indicators of the financial condition of the borrower.

Consolidated balance sheet showed that the structure of the balance sheet corresponds to the development activities in the field of construction and management of the commercial and residential real estate. So most of the assets, namely $80 \%$, accounted for fixed assets, i.e. non-current assets of the company at the three analyzed reporting dates. The share of current assets is not more than 


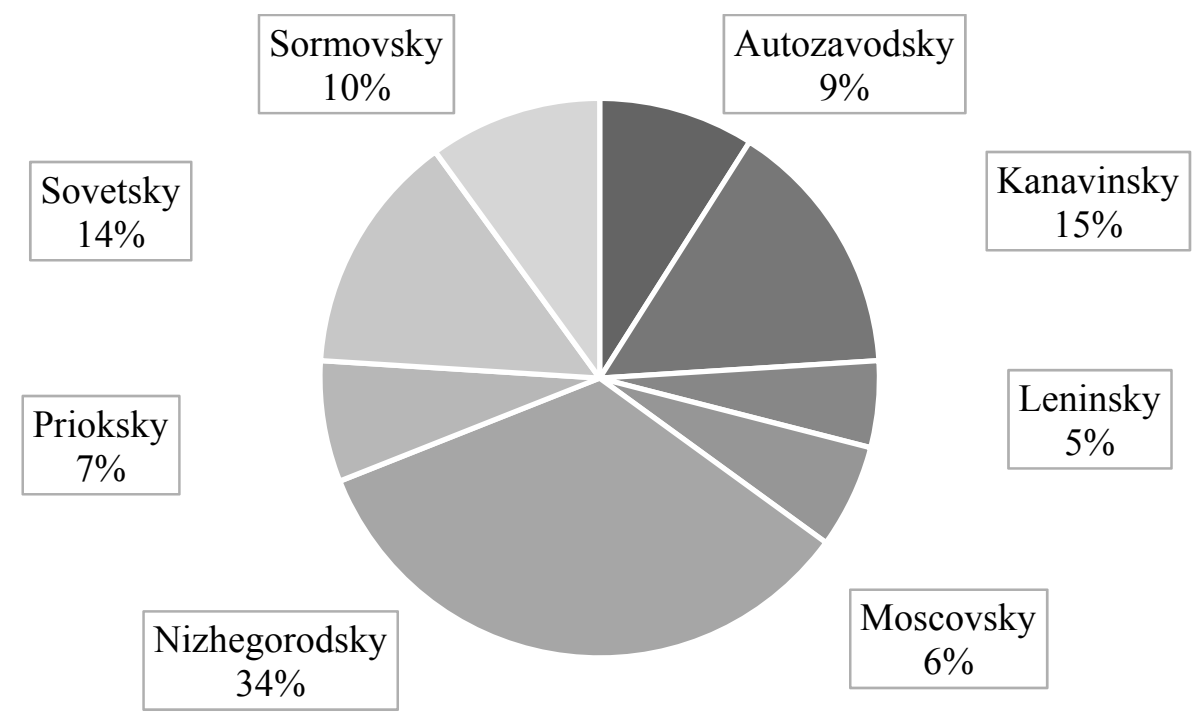

Figure 2. The volume of supply in the rental market of commercial premises for April 2017 by district division in Nizhny Novgorod

Source: The author.

$20 \%$, the structure of which is distributed between cash and receivables for + (plus) - (minus) $5 \%$ and $13 \%$, respectively.

Liability of the group of companies in its structure, in the face of long-term capital, tends to decrease. This decrease in the balance sheet longterm debt is because the terms are suitable for the payment of ball payments (balloon - payment) on the main debt of early loans for the construction of fixed assets. Thus, long-term liabilities have an average weight in the balance sheet at $60 \%$, and at the last reporting date, the fourth section of the balance sheet form was $57 \%$ of the total balance sheet structure. The remaining share is accounted for by the company's equity capital, where retained earnings have a significant weight, increasing year-on-year.

Immobilized assets at the last date are about 8 million. RUB. Mobile assets, forming the second section of the balance sheet, is much lower and is not more than 1.7 million. RUB. Equity and debt capital is correlated as 40:60 on 01.10.2018.

Expediency description of negative working and working capital is not due to as such participation of working capital in the current activities of the group of companies in the main form.

Express assessment on the basis of good balance (Table 4 ) showed that the company's activities are consistently positive as over the last three reporting dates there has been an increase in the balance sheet currency, which is especially important for development activities - there is an increase in its presence as a key player in the market through an increase in the share of construction. The rate of growth of working and non-working capital occurs as necessary and is carried out not by sharp, but by a well-balanced increase in assets. An identical trend is observed in the ratio of equity and debt capital.

The company's capital formation policy is based on the expediency of increasing the borrowed capital when new investment projects are required, and the debt burden on the "old" obligations is fully covered by the flows under this project. There is no uncovered loss in the consolidated balance sheet, which also has a positive impact on the valuation.

Assessment and analysis of the dynamics of net assets is most relevant. Thus, the company's net assets increase while maintaining the size of the authorized capital. Therefore, the group of companies is not threatened with liquidation or increase of the authorized capital unscheduled the risk of raising funds from business owners is levelled, a good level of maintenance of the authorized capital (Table 5).

The analysis of solvency of the group of companies was carried out by dividing and grouping the company's assets by their liquidity and grouping liabilities by maturity, then the analysis of solvency and liquidity through the coefficients (Table 6). 
It was found that the group of companies has no inappropriate distribution of assets and liabilities. From the table of correlation of groups the obvious ability to cover fixed-term liabilities and short-term loans, the purpose of which is the financing of stocks and other working capital (Table 7).

Another approach to assessing the liquidity of the balance sheet is the functional approach, which is the fairest in the assessment of Russian companies. This technique reflects the functional balance between assets and liabilities in their main cycles: operational, investment, monetary.

The table below shows that to finance current assets, i.e. stocks, the company will need to increase accounts payable. Still, due to the specifics of the activity, this is not necessary. Sufficiency in the financing of non-current assets is present, even a surplus is formed, in the extreme case, the civil code can redirect it to investments, maintenance of existing facilities or finance reserves taking into account possible risk. To assess the creditworthiness of this fact is insignificant and does not pose a threat to the solvency of the loan. It also applies to the ability of the company to pay its contractors (Table 8).

The analysis of absolute solvency by the degree of liquidity and maturity of liabilities in dynamics and at the reporting date showed a satisfactory result. The Bank's interests do not affect some non-compliance with the rules of the methodology of analysis. Now the stage of estimation of coefficients.

The ratio analysis of the balance sheet liquidity from the point of view of assessing the future creditworthiness and forming the policy of distribution of funds by types of assets is satisfactory. As of the three reporting dates, the group of companies has a sufficient level of relative liquidity indicators for the consolidated balance sheet. The overall solvency is more than $50 \%$, and a small degree of manoeuvrability of operating capital and security of current assets does not pose a threat to the issuance of credit funds and the establishment of a limit (Table 9).

The financial condition of the group of companies was estimated by five main factors, one of which is the capitalization ratio, which characterizes the rate of borrowed capital to equity. In the case of financing of an existing project, when the funds will be allocated largely for refinancing and the costs of current activities, the value of 1.57 at the last analyzed date was acceptable. If the goal was to build from scratch, for the Bank this is already a risky entry into the project since a large degree. However, knowing the fact that at the end of 2016 came the obligation to balloonpayment for other loans, potentially the ratio may decrease, then the Bank increases interest in the issuance of funds.

Financial autonomy is optimal, fits into the average indicators, the growing share of retained earnings, balancing long-term funds and the terms of their payments (Table 10), and provides financial stability.

The analysis of financial stability was continued by the method of the sufficiency of sources of financing of reserves. According to calculations (Table 11), it can be seen below that the company's policy on the residual principle forms reserves based on long-term sources. Summary assessment of strength: average, acceptable.

The final score on the method of class boundaries is presented in Table 12. On the reporting, three dates were awarded grade 3 : this is the civil code, the financial condition of which can be assessed as average and stable. In the analysis of the consolidated balance sheet visible to the weakness of the individual financial indicators: nonemergency precarious financial condition due to the prevalence of borrowed sources of funding, but there is some current capacity to pay, secured by cash, accounts receivable, and a small number of stocks. In business relations with such an organization, there is hardly a risk of loss of funds, but the fulfilment of obligations on time is doubtful. Therefore, control and sanctions are necessary to maintain financial discipline (Table13).

The financial result of the company also shows good dynamics in terms of revenue and net profit. Ledger has a minimum cost, which refers to some materials used in the construction of objects or the cost of third-party property management services. The group showed good profitability, which is even slightly higher than the average industry profitability (Table 13).

As mentioned earlier, the company shows good profitability for the main activity. The profitability of sales is the highest since there is practically no cost in the process of managing the rental areas of the shopping centre, and then the decrease in accounting profitability is due to payments for 


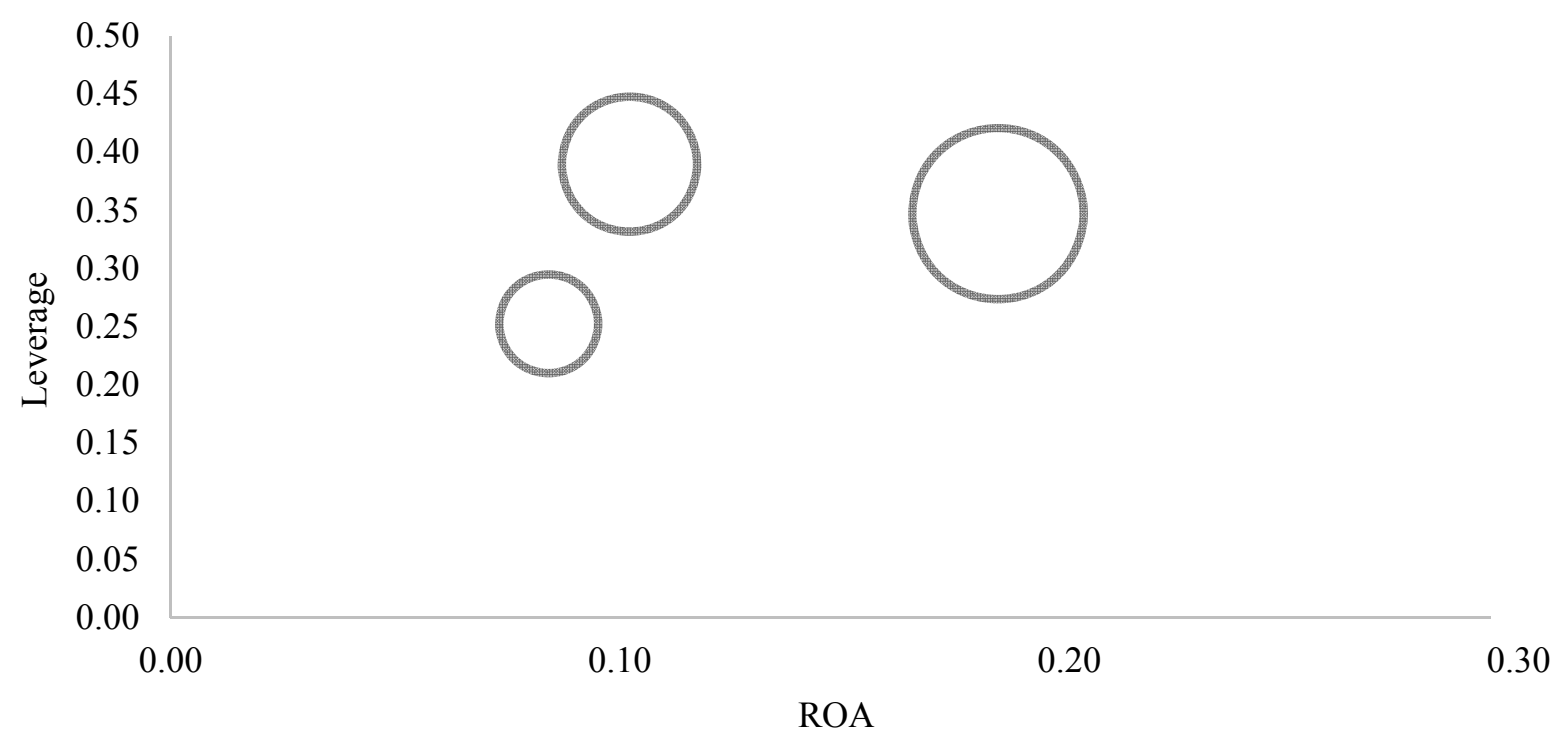

Figure 3. Matrix for evaluating the financial results of ROE

Source: The author, based on the financial analysis of the financial statements of the client.

management and administrative expenses. In general, the profitability is higher than the industry (20\%) by $5-15 \%$, depending on the period of entry or renewal of the Group's retail space. Largely, the indicator is higher than the sectoral value in the regions, depending on the market share of the Civil Code and large-scale construction of the commercial and residential real estate.

From the point of view of profit management organization can be noted efficiency. The sustainable growth rate shows that the company manages to maintain and even increase its own capital through a constant increase in cash and maintain a return on equity of 35-25\% (Fig. 3).

The Group shows the effectiveness of using fixed assets and equity, so for each ruble invested in the assets, the company receives from 30 to 51 kop. with an increase of $60 \%$, and equity capital, taking into account the effect of borrowed funds, it can generate up to $100 \%$ repayment of funds. In general, in terms of resource productivity, it can be determined that the group of companies manages to increase the effectiveness of its activities by managing commercial areas with an increasing effect (Table 14).

The conclusion after the financial analysis of the Group is positive. Evaluation of the activities of the Civil Code is entirely consistent with the specifics in the field of construction and property management. Financial performance is stable. The key positive factors were the absence of losses, the decrease in debt obligations, positive growing net assets of the group. The operating activities of the borrower are not related to the taxation of other countries; it does not have any claims for the payment of any compensation. The main subsequent crediting factor will be the assessment of the credit rating and the ability to fulfil covenant conditions.

\section{Algorithm of Investment Project Risk Management}

The management of the financing program after conducting a financial analysis requires systematization of the main provisions/requirements for the borrower to successfully implement the project and obtain a sufficient flow.

In the practice of corporate lending by banks, there are several provisions that, based on the legislation of the Russian Federation and internal regulations, describe key managerial and financial aspects of the client's activities to minimize credit risks. These restrictive lending components after the approval of the basic wishes of the terms and amount of debt funds, the review and validation of the forecast and stress models are covenants. There is a list of the most commonly used mandatory requirements for customer performance. Their number does not exceed 15 requirements. Some covenants were developed and assembled into a single system for the project of graduation qualification work, compliance with which will allow monitoring the effectiveness of the investment project and significantly reducing the risks of insufficient accumulation of CFADS flows.

First, we present several special conditions for the borrower in terms of management activities: 
1. Maintaining top management throughout the entire process of supporting an investment project with credit funds.

2 . The inability to attract additional credit funds from other (other) banking institutions, at least without a written agreement of the credited bank to control the client's debt load and its financial stability.

3. Opening of bank accounts for 50 million roubles.

4. By 2020, the closure of accounts in other banks to control the operations with project funds.

5. Possibility without the acceptance of funds from the client's accounts in case of violation of the terms of transfer of funds/in violation of the financial discipline of the borrower.

6. The obligation to conduct normal operating activities, based on which materials were previously provided for a comprehensive analysis.

7. In case of violation of the requirements by the client, the possibility of immediate repayment of the loan.

8. Provision of financial statements.

9. Providing a financial model.

10. Report on court cases and amounts to be reclaimed.

11. Acquaintance with the policy of optimization of the expenditure part of the main activity.

12. Carrying out and registration of all operations with counterparties strictly in law.

13. The possibility of introducing new restrictive and controlling conditions in the event of major changes after the next semi-annual analysis.

This series of management covenants is aimed at maintaining a stable and understandable type of activity of the borrower. Financial covenants focused on the effective risk management of the project, whose action is triggered by the mutual deterioration of all previously identified factors:

1. DSCR not less than 1, 00.

2. Indexation income can be reduced by no more than $5 \%$ of the current indexation index.

3 . The percentage of space loading specified in the financial model should be at least $86 \%$ before 2021, at least 91 ; subsequent years starting in 2021.

4. The indicator of operating expenses cannot be exceeded than $30 \%$ of revenue without VAT based on the adjusted current financial model.

Financial covenants focused on the effective risk management of the project, whose action is triggered by a single-factor deterioration of the factor under consideration:

1. DSCR greater than 1.00.

2. Reflection of inflation expectations in the forecast to a growth of $10 \%$ of the current figure.

3 . Do not exceed the reduction in rental rates $i$. per cent indexation of income from current activities in the model by more than $12 \%$.

4. Excess OPEX should not exceed $12 \%$ of current expenditure percentage.

5. Reducing the load area of the maximum possible level can reach - (minus) $12 \%$ of the current load level.

The total financial covenants that must be enforced are TD/EBITDA less than or equal to 0.7 before 2019 and less than or equal to 0.5 after 2019; EBITDA/TD is greater than or equal to 1.

Security covenants of nature, the significance of which is concentrated around the collateral object and confirming the profitability of the industry:

1. Making a mortgage on the object.

2. The impossibility of laying the mortgage object in other banks.

3. Providing annual marketing research by one of the leading companies.

4. Providing a report of the appraiser of the value of the collateral property.

Performing a covenant requires unconditional control over the usual activities and conditions of the loan agreement. In the extreme case, failure to comply with the signed mandatory conditions of the transaction imposes additional risks on the bank. In connection with this fact, the decision can be achieved through the penalties prescribed and agreed with the client, which are imposed immediately and progressively.

The number of penalties that can be applied to the borrower in case of non-compliance with the prescribed and approved covenants:

1. Payment of a fine as a percentage of the body for a long time or in a predetermined amount. This measure is advisable to use only for minor violations or as an alternative to an early collection. In contrast to the increase in the interest rate on loan is not enough stimulating act because most often bears short-term and one-time nature, but can be realized introduced.

2. Interest rate increase. The measure that most likely will not be applied to this client, but it is possible in emergency cases of violation of covenants. This mechanism will increase significantly 
more pressure on the client as it stimulates the speedy elimination of the violation.

3. Termination of funding.

4. Termination of the issuance of new trenches.

5. Early loan repayment is a measure indicated as a covenant.

During the actual and final signing of the loan agreement, subsequent questions may arise and the company manages the concepts and narrow moments. Mutual and mutual interest calls on both parties to clarify and characterize all the incomprehensible calculations and concepts of a credit transaction.

However, the bank anticipates some incorrect actions of the borrower, which, in his opinion, due to the interest of the company, can significantly distort the current and subsequent financial position of the company, and the ability to fulfil its obligations. These features include the following items:

1. Do not transfer payments for the inflow of funds that form revenues beyond the reporting and agreed period from the base of contracts.

2. Do not make technical repayment of shortterm loans to reduce the indicator of the main debt of the Civil Code.

3. Before and before signing the main financial and other covenants, stipulate possible seasonal fluctuations recorded earlier by the Civil Code, as well as a decrease in operating indicators due to the length of the production cycle, etc.

In the event of an unforeseen crisis and previously unrecorded emergency liquidity, financial stability and other reasonable and real changes in accordance with the legislation of the Russian Federation, the client can work with the bank on some possible measures to improve the terms of the credit transaction on the following issues:

1. Reducing the basic interest rate on loan.

2. Reduction of issuance and maintenance fees.

3. Transition to a floating rate based on MIBOR (relevant for larger borrowers)

4. Minimization of fees for related banking operations.

5. Extension of crediting terms and change of payment schedule for principal and interest payments.

6. Mitigation of financial covenants, but not the possibility of reducing financial covenants below the minimum level for a bank.

7. Convenient receipt and redemption schedules, levelling seasonal surges, if any, and so on.
The final step in working with project risks is the need to finalize the text of the loan agreement in accordance with the Civil Code of the Russian Federation. Obligatory parameters will indicate the subject of the agreement, the transfer of borrowed funds, the interest payable, the procedure and time for the return of credit, the responsibility of the parties for violation of the terms of the transaction. Thus, it can be stated that the project will be safe from a legal point of view, and therefore it is an interest to both the owners and the bank.

\section{Financing Optimization}

\section{Financial Model Application for Making an Investment Decision}

The initial forecast consolidated model of the Client is presented the borrower's vision of the basic assumptions of the project, and its estimated need for loan funds has three input parameters, one of which is inflation equal to $4 \%$ annually according to the forecast of the Ministry of Economic Development of the Russian Federation.

Other prerequisites are the percentage of rental rate indexation for tenants of the shopping centre at $3 \%$, as well as transaction costs in the amount of $28.3 \%$ of the annual revenue of the forecast cash flow model. The need for loan funds is estimated by the client for 1500000 thousand rubles, under the proposed $11.8 \%$. The forecast step is ten years with quarterly breakdown and summation of the annual flow.

The original model contains a number of errors and incorrect displays of the cash flow of GK from the main activity. A clear discrepancy is the lack of consideration of the workload of areas of the rentable area of the object. After all, this premise is very important for commercial real estate. Consequently, the addition of the base model was carried out.

The model provided by the client also failed to withstand the process of stressing key indicators it can be noted that both the initial and the stressing are punched by the DSCR coverage indicator of 0.96 and 0.92 , respectively (Table 15).

Moreover, the LTV indicator exceeds $80 \%-$ these are additional threats to the financial stability of the client and his creditworthiness in the first three years. Consequently, three years of lend- 
ing is a significant time, which can significantly change the overall picture of the transaction on the committee on making a deal. Other credit analysis indicators are positive. For example, the debt is covered by an annual EBITDA indicator on average three times, the interest payments on a loan to the same indicators are covered on average more than 20 times in the absence of changes in the model. However, the economy of all indicators is not always reasonable, realistic and meets the requirements of the bank.

Thus, based on the above adjustments to the financial model. Crediting is possible on the following general conditions (see Table 16).

Based on the modified and augmented calculations of the model, the indicators of the base covenants were recalculated. Significant improvements in DSCR and LTV provide a more robust, financially sustainable lending program. The overall economics of the project (Table 17) shows a good result cumulatively over ten years. Therefore, the company will be able to accumulate EBITDA for 25 billion roubles, to cover interest and the body of the loan during the specified period.

Thus, you can testify financial bonitet and sustainable reputation of the project. The borrower's credit rating was evaluated by evaluating the performance of the baseline credit process and determining the borrower's alternative rating as of the last reporting date.

Let us give the calculation of the alternative calculation of the rating of a medium-sized business client according to the method, which is in the open-access of MSP-Bank.

The result of the calculation using the alternative formula of MSP-Bank with weights of 0.35 for qualitative characteristics and 0.65 for quantitative showed that a potential borrower has 1 credit rating with a total score of 92 out of 100 (Table 18).

The Bank's calculated rating, as well as previous lending experience with absolute coverage of the borrower's previous obligations, do not undermine customer reliability. According to the internal automated system for assessing the borrower's rating, the $\mathrm{B}++$ rating was obtained, which is slightly lower than the alternative indicator. Still, the internal rating is high and good.

The economic security of the client as a potential borrower took place in such areas as litigation and arbitration cases of a group of companies, the presence of lawsuits in the company's top management, the credit history of the company, A-bel history, professionalism of the manager, business reputation, and financial indicators stability and ability to fulfil obligations. Identification of risks to confirm the internal rating of the group and its reasoning required the study of such materials as a constituent and financial documents, documentary evidence of property and rent if such an agreement exists, as well as management reporting and turnover balance sheets.

In addition to the estimated rating, the credit rating is based on the calculation of the present value of the flows to cover debt obligations to the bank, i.e. cash flow CFADS. Two options are being considered: the first is for the base adjusted bank model; the second is the same stress-based model for the main bank scenario. From the table values given below, you can see the adequacy of the reduced flow in terms of LLCR for the period of the project crediting (Table 19).

Similarly, to the base model of the bank, LLCR indicator for this project is kept at a good level. However, it should not be forgotten that this is not covering the term on time, as it is prescribed in the loan agreement. This accumulated and reduced coverage of debt obligations in front of the Bank of the Group, therefore, this indicator can be used as a safety cushion or a guideline on how many CFADS are not on an annualized basis and will be able to cover liabilities on the date of their conclusion. A kind of stress and risk gauge, which, as you can see below, meets the requirements of the bank (Table 20).

The two-factor Altman model, which has a correlation with the credit rating, showed that the bankruptcy of this borrower is no more than $50 \%$. If we correlate the rating of the internal calculation with the calculated one in Table 20, it can be noted that in principle, they are comparable. The risk of bankruptcy should be feared only with a larger increase in borrowed funds, the appearance of losses and a decrease in the value of the Group's assets (Table 21).

Altman's five-factor model in contrast to the two-factor model, it is harder to assess the level of a company's bankruptcy, since highlights its high debt burden with a minimum of its own working capital. Other bankruptcy assessment models were even more irrelevant. Firstly, the company is not listed on the stock exchange - it is a me- 

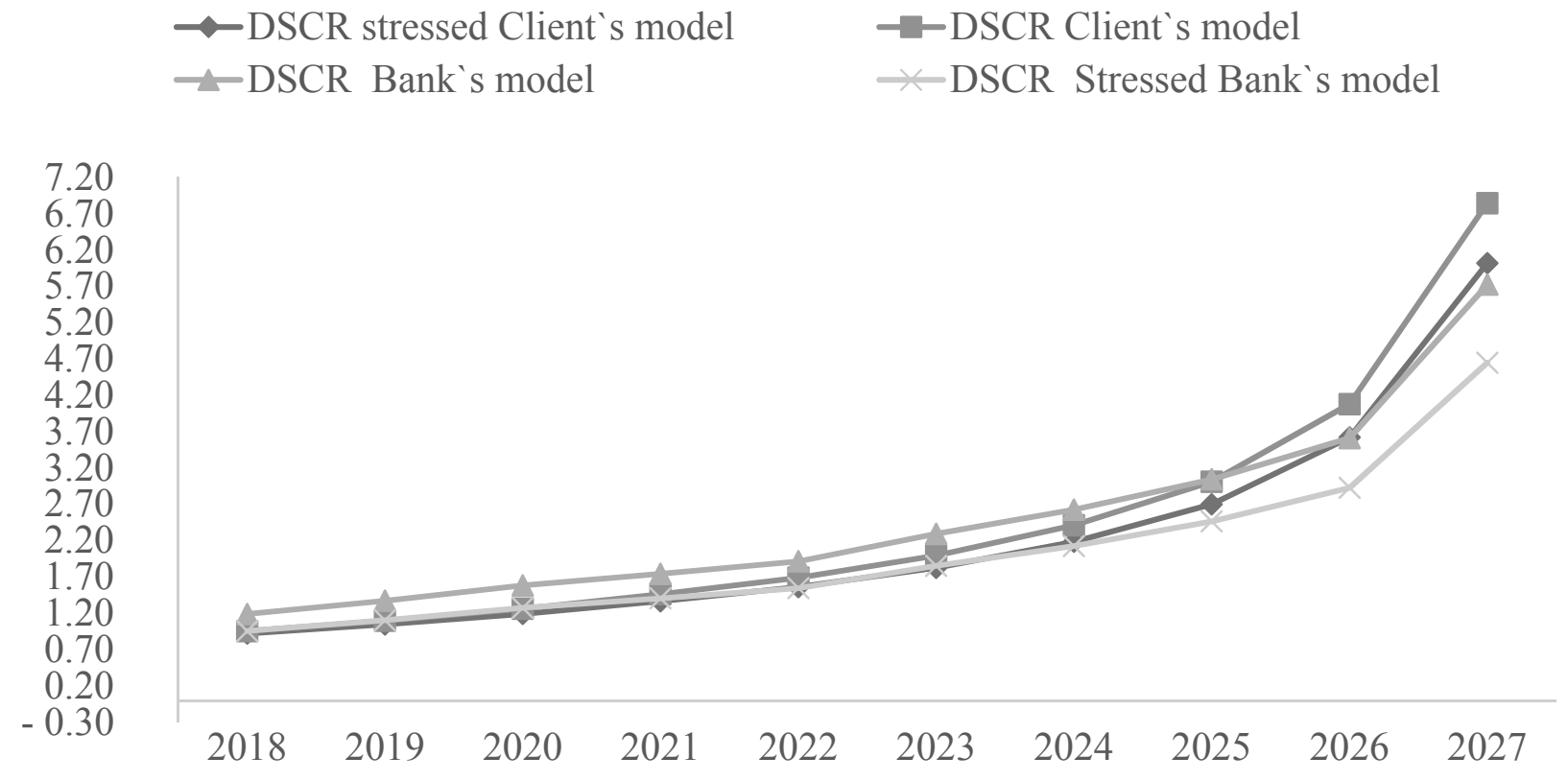

Figure 4. Comparison of the DSCR parameter for the Customer and Bank models with different start-up loans Source: The author, based on the developed financial model.

dium and regional business focused on a narrow segment; secondly, working capital is given a lot of attention in assessment models, and for credit analysis in the case of this project, this is not a significant factor.

\section{Stress Testing of Key Assumptions and Financial Covenants}

The scenario of deviation of some parameters of the financial model, refined and mutually approved with the client, was conducted in two directions:

1. Deviation of three factors (inflation, rental rate, space loading, OPEX, i.e., operating costs) of the financial model by + (plus), - (minus) $5 \%$ of current values.

2. The alternate deviation of the same factors, all other things being equal, from 2 to $12 \%$ of the effective values in series.

Stress - scenario is an important and necessary stage for drawing up and justifying the stop factors in the process of crediting a client. The alternate deviation of the factors is justified by the methodological practices of the bank, which provides loans to the client. The key rationale for this range of deviations from the current value is the peak and crisis average industry indicators.

Three-factor simultaneous change of drivers and initial prerequisites of the adjusted banking financial model within 5\% decrease and increase showed that this is the most aggravating scenario of the development of the client's activities.

The alternate deviation of factors in the range from 2 to $12 \%$ and the impact on the total flow CFADS and average DSCR (Tables 22-29).

Conducting an alternate analysis of the key factor deviation for CFADS flow changes and the average DSCR values over the entire project loan period, it can be noted that no single factor, ranging from 2 to $12 \%$ of the set value in the model, has a significant effect on the project's feasibility according to the covenant and their changes. The client can cover the body of debt and interest for a fixed period of 10 years. However, this statement without additional control is correct only with the change of only one factor of the model.

The graph comparing the DCSR by EBITDA (Fig. 4) allows you to analyze the viability of the project for one of the financial covenants in comparison with its initial values of the client model and the final value of the bank model. You may notice that the reduction of the loan amount by 300 million rubles allowed providing DSCR under the actual scenario at a level of more than 1.0 and in a state of risk a minimum decrease only in the first year of the start of funding the Lotos Plaza program.

Financial covenants of a basic and obligatory nature, which are beacons of the entire loan pro- 
gram, were also calculated for the model with deviations from the fact. One can notice only one significant deviation - this is a decrease in the DCR of the indicator below the established acceptable minimum of 1.0. CFADS - the flow is not enough at the end of 2017 to cover the borrower's company's loan portfolio.

The lack of funds is about 50 million roubles. However, from the second year of crediting of the SEC project, the excess liquidity attributable to the portfolio at the end of the year is 200 million roubles. This gap arises in the conditions of the stress of the client model for all previously selected key parameters. It is important to emphasize that the coverage gap does not detract from the insignificant amount of the LTV indicator, even if there are deviations of the model. LTV (loan amount to the market value of the collateral) is $67 \%$.

\section{Investment Project Attractiveness and Ways to Improve the Company's Financing Structure}

High debt load, an acute shortage of funds and, as a result, no chance to pay off loans and credits on time. This situation is familiar to many Russian companies, and it is by no means hopeless. Convince lenders to wait for money and not lose the company can if you plan the upcoming negotiations and work on debt restructuring in advance.

Therefore, it is worth starting with determining the real state of affairs of a company, namely, with an honest answer to the question of whether a company can, in current conditions, be a timely or minimum delay to service loans. If this is not possible, it will be more than justifiable to hold a meeting of all creditors. During such a meeting, it is important to describe the current situation, to inform them about plans for its improvement and to agree on further. Steps. Do this before the company is unable to pay its obligations. At such a meeting, it is important to smooth the effect of unpleasant news, to demonstrate openness and readiness for dialogue.

It should not make a typical mistake at the very first stage and try to negotiate separately with each lender. Reaching agreement on anything in this mode is extremely difficult because each of them will have its point of view and often distrust of all other interested parties. At the first meeting, the lenders are likely to ask for information about the total amount of debts, available cash, forecasts for future cash flows, and a vision for the business. Of course, ideally, it would not be superfluous to at least outline an anti-crisis action plan. Nevertheless, even if some data is not yet available, the cash flow projection is yet to be developed, and some of the expected questions from lenders it is not clear what to answer, you still should not delay the beginning of the dialogue. In such cases, it is permissible, if during the meeting specific issues of creditors are recorded, which did not find an instant answer, as well as the dates, in which the company will provide all the missing information.

Restructuring is always associated with substantial expenditures not only of money but also of time, as well as managerial resources. As a rule, this aspect of management is greatly underestimated, which sometimes leads to the breakdown of all work.

According to experience, negotiations on debt restructuring for a large company can last about a year or more and take place under tight time pressure, so the whole process should be streamlined and planned from the very beginning. Namely to appoint the employee (and in especially difficult cases several) responsible for debt restructuring. In a medium-sized business, a financial director usually becomes such a specialist. In a large company, one of his deputies responsible for raising funds, for example, the head of the treasury department. It should be the first working contact for all creditors, coordinate the activities of various services and consultants of the company, have sufficient authority to make operational decisions and regularly inform management about the progress of negotiations, agreements reached and problems encountered. Besides, you need to realistically evaluate and reflect in financial forecasts how much a company will be saved from debts. In the case of a large business, the upcoming costs can be in the hundreds of thousands of dollars. This money will be spent on remuneration to the coordinating committee of creditors, payment of services of attracted consultants, external lawyers, etc.

Once a long-term financial model has been created, it is necessary to proceed to agree on the final terms of debt restructuring. For example, if a company is not able to repay loans during the year, according to forecasts, it would be wise to try to 
negotiate annual deferred payments in exchange for additional collateral and (or) higher interest payments paid after the restoration of solvency.

The borrowing company will have to take a number of painful, but necessary measures, such as the rejection of dividends, a sharp reduction in capital investments, the provision of additional guarantees and collateral, forced sale of individual assets to make payments to creditors. Of course, all the agreements reached will be completed with a set of documents, namely: agreement on longterm debt restructuring (there may be several for different groups of creditors); agreement on the nature and methods of monitoring the company's activities on the part of creditors; agreement on additional guarantees and collateral provided by the company; agreement on further cooperation of creditors. After debt restructuring, the coordinating committee usually loses its powers; various documents confirming that the company has met the agreed pre-conditions for restructuring, and much more.

When the papers are signed, the matter is small - to strictly execute the agreed payment schedules and implement the measures for increasing cash flows foreseen in the forecasts, for example, to increase business efficiency, improve liquidity management, reduce costs, increase sales, etc. In short, it remains to do all that was promised. By the way, lenders will be very careful to observe how successful the company moves in this direction and implements the announced plans. Agreements with creditors usually provide that until the full repayment of all restructured debts, the company undertakes to regularly provide them with detailed information on the state of affairs. Moreover, creditors will carefully check the accuracy of the data. The standard reporting package for lenders includes information about cash in accounts, short-term cash flow projections, updates to the financial model, etc.

To retain market position and minimize losses, many companies have to go through significant changes. Some markets are opening up; others are shrinking. The staffing of enterprises is becoming more mobile - both quantitatively and qualitatively: yesterday's leading specialist may take the position of financial director, and the new accountant will replace the experienced accountant. Instead of a clear development plan, enterprises are working on several alternative strategies, which can often directly contradict each other.

Banks simply do not have time to track all changes in the corporate market and are not always ready to offer customers the products and services that match their real needs. The needs of each particular company, in turn, will be easy to predict if the bank will know which way the company intends to continue its development soon. Typically, a company will implement several of the strategies listed below, one or two of which will be key.

Improving and increasing the investment attractiveness of a client from the segment as a current borrower is a rather difficult process. Firstly, a real hunt in large banks follows the clients of this order with good financial stability, experience and a strong modern development strategy. Secondly, of course, bank managers can advise how to increase the attractiveness of the company, but most likely, it will take a lot of time, and the client will refuse the bank services. Indeed, improvement can be from two sides, finance - changing the perimeter of the Group, which means transferring activities or other costs of opening a new legal entity, qualitative - changing and revising the company's strategy and vision in the industry. Both ways, in a global sense, unsuitable for the Group, but local changes are possible if they are mutual. First, we consider possible options for a local strategy change, the importance of which is described in the theoretical chapter. They are presented below:

- Import Substitution - Production of Goods and Services for B 2B or B 2C, allowing to replace substantially expensive import.

- Export for hard currency - strengthening positions due to exports of goods and services that will ensure the best conditions for staff and invest in production.

- Revolutionary cost reduction through automation, process reengineering, outsourcing, appeals to the Russian counterparts of imported components.

- Entering the mass market - focus on the mass customer and offer him products/services that meet his needs and financial capabilities. This strategy allows you to save brand investments and use scale effect on production.

- Technological breakthrough - bringing the unique to the market product or use of unique 
technology (for example, a significant reduction in the cost of and production time due to full or partial automation).

- Support instead of production - reorientation production with a $t$ in a company for accompanying, maintenance, repair and minor improvements. With this, as a rule, the company retains its previous customers and can also lure customers from its competitors.

- Blue Ocean - with a fundamentally new product, actually forming a new segment and essentially different from the offers of competitors. It allows creating an advantage and eliminates competition even in the medium term.

- Strategic customer - key position a small number of contractors (maybe one) sustainable strategic customers.

- Strategic investor - the development of the company through funds oriented strategic investor in the medium or long term.

The following two strategies cannot be attributed to the winning strategies. However, they allow you to save the organization or protect the interests of its owners that for Bank means saving the client and the possible continuation of the relationship in perspective.

- Compression of business is a significant reduction in the volume. Maintaining core business and key competence.

- Freezing of business - termination of the main type activities or significant change in business processes (for example, the transition from the pipeline to the project organization work) while maintaining legal status and some assets.

Having a full client profile, the bank will be able to conduct a clear base segmentation and offer companies those products, which they need now. Usually, businesses are reluctant to share information. Therefore, to get as much data about the corporate client, you need to provide him with useful data, which will help to win loyalty to your bank. For this:

- Offer your customers information about the state of the bank, the current grocery offer and plans for the development of new products and services. It will allow you to count on customer interest. and getting the necessary information from him for further interaction.

- Create a bank profile in an accessible language for the client with a demonstration of the dynamics and position regarding competitors. Becoming a source of state information your bank (balance analysis, basic standards, etc.) you can save potential time customers and keep them from getting poor quality data from competitors and non-specialists.

- Regularly inform the client about changes in the product portfolio of the bank. Therefore, you will demonstrate the ability to fulfil obligations to schedule a new contact and expect that the client will contact you in case of receiving an offer from another bank. At the same time, it is important to bear in mind that when long sales cycle conditions for a standard product or individual offers are subject to change strikingly and not in favour of the client.

Since it is impossible and irrational to provide complete and up-to-date information for all customers, it is advisable to establish a direct relationship: the more important the customer, the complete information about it you should have. To understand which client is of higher priority, and which less so, segmentation by the following parameters will help.

Client's business dependence on the Bank:

- Assessment of client company dependency from operational services, lending and other banking services. In some cases, valid loan agreements or technological services of the bank can make the client so dependent that he cannot in the medium prospect of abandoning bank services.

- Number and variety of financial products used by organisation (including services competitors): only RKO and RBS; RCU and loan products; RCU and various payment products and services; RKO, loan products and payment products and services.

Dependence of the Bank on the client:

- Client grouping by customer shares in assets/liabilities bank.

- Client grouping by the share in the bank and specific income branch/division.

- Client grouping by Non-financial importance of the client (political considerations reference client for a specific segment pilot client for a particular segment/product).

Customer business dynamics:

- Evaluation of business dynamics by customer turnover or reporting. It is advisable to divide customers into groups and compare with 
the average indicator for the corresponding industry segment: dynamic developing, stagnating or in crisis.

- Defining the main strategy, which the organization follows.

To reduce labour costs and avoid ineffective negotiations with the client, save the parameters in your CRM system client request and bank offers. In this case, be sure to indicate at what current rates and rates and at what point they were identified. For planning follow-up communication with clients, an auxiliary report can be useful showing all current sales processes for which key conditions were defined quite a long time ago and have changed a lot.

Please note that not only the fact of changing conditions (which is sometimes unavoidable) is important, but timely and honest communication with the client. To work more effectively with a corporate client, the bank needs to build a new product-segment matrix. At the same time, managers should group existing and prospective banking products according to alternative customer strategies described at the beginning of the article.

Corporate products are not sold to corporations, but to specific individuals who represent them. The sales cycle for an enterprise can be accurately achieved, up to several months; the sales cycle for an individual is usually shorter.

Establish interaction between corporate and retail divisions of the bank to offer and sell banking products natural individuals promptly - employees of the client company (not only at the level of Private Banking and Affluent, but also in retail). The main goal, in this case, is not to sell to a retail customer, but to keep.

The traditional approach to planning concerning last year's indicators may not work in current conditions due to uneven development (and often fall) in various sectors of the economy and significant devaluation. The effective transformation of this approach directly depends on how clients are distributed among managers: if there is a strict sectoral division, each branch uses its own coefficient relative to the previous period; if there is no strict sectoral division, uniform indicators are used for all client managers, determined on the basis of the sectoral structure of the client base of the bank itself. The forecast and plan for large clients should be made separately for each client, not based on industry trends. The reason for this is that the client base with which it works a specific manager may differ in its sectoral composition and importance customers.

\section{Conclusion}

Corporate banking is a core activity for banks and plays a pivotal role in the economies they serve. Roughly, one-third of the total bank lending and $20 \%$ of the total asset base are dedicated to corporate banking activities. Similarly, the activities of corporate banks are a cornerstone of the economies in which they operate. Lending from banks still represents the largest source of debt funding in Europe and Asia; and even in the predominantly market-oriented US, bank lending still accounts for a significant $31 \%$ of all debt funding.

Debt financing of investment projects is a common tool for raising funds, the arsenal of which includes more than ten general financing schemes for various types of investment programs of companies. The use of debt financing provides the company with many useful and effective measures, namely: taking advantage of financial leverage, risk sharing, auditing and conducting multidimensional business audits, reducing the debt burden, covering the lack of own funds in the investment process and some other benefits.

Recently, one can observe how the business community is growing and is seeking to implement new initiatives of various projects. However, it is clear that investment funds are no longer becoming, competition is growing, the pursuit of superreturns is underway, and the funds themselves are not getting cheaper. Consequently, for a project that "costs" attention, it is necessary to work out in detail the scheme for financing investment resources, as well as carefully select arguments from both the financial and non-financial sides. Similarly, an analysis was made of the presented project in the final qualifying work. The aim of the project was to expand the shopping and entertainment center and cover its previous debt to another bank. The complexity of the implementation of this project by the method of debt financing through a corporate lending scheme, namely project financing, was of an average complexity because simultaneously treated both a structured and unstructured transaction.

Thus, after a comprehensive analysis, the project of the A'bel group of companies showed its 
viability, high probability of implementation and economic efficiency for both sides of the credit transaction. Initial potential conditions were in doubt because of the substantial break in the key resultant DSCR. The adjustment made it possible to reduce the risk, improve the DSCR and develop an adequate, fairly voluminous, but effective system for managing cash flows and important aspects of the Group's activities to cover loan commitments.

The project's economy is well represented through the key DCR coverage indicator (Table 30).

Summing up the project and assessing the attractiveness of corporate lending for the current client will be helped by the widely used Rule Six C methodology (Table 31).

Prospects for the development of debt financing is an evolutionary path. Individual approach to the project and its stakeholders, as well as to the toolkit for attracting investment funds. Undergo significant changes will also be industries considered by investors, and in the banking sector is a customer rating system. However, one thing is obvious, the indicator of stability and civilization of the debt capital market is an increase in the term of "work" of borrowed funds (duration) available for the corporate sector and the quality of sources of covering obligations to the investor/lender. It is also undoubtedly an increase in activity on the debt capital market itself and its constant transformation in response to the demands of the times and the requests of companies.

With corporate lending as a method of an unstructured and non-securitized product, changes are expected for the better with respect to the improvement of methods and methodologies for the assessment and analysis of legal activity, as well as a rating system. The score will be complicated and seriously inclined to the reputational component with a share of more than $20-25 \%$ in the overall rating.

Summing up, it is possible to note the prospects of the debt borrowing market for both companies and specialists in this field.

\section{References}

Abrams, Jay B. (2010). Quantitative business valuation: a mathematical approach for today. 2nd ed. Barilenko, V. I. (2016). Analysis of financial statements: a textbook. 4th ed. Moscow: KNORUS.

Belikov, T. (2017). The Minefields of Project Finance: A Survival Guide for Credit Workers and Investors. Moscow: Alpina Business Books.

Blank, I. A. (2015). Management of capital use. Kyiv: Nika-Center, Elga.

Blank, I. A. (2015). Management of financial stabilization of an enterprise. Kyiv: Nika-Center, Elga.

Bobylev, A. Z. (2018). Financial management. Problems and solutions: a textbook for masters. Moscow: Publishing Yurayt.

Brigham, Y. (2009). Erhard M. Financial Management. St. Petersburg: Peter.

Brusov, P. N., Filatova, T. V., Lakhmetkina, N. I. (2017). Investment Management: Textbook. Moscow: Infra-M. Damodaran, A. (2019). Investment appraisal: Tools and methods for evaluating any assets. Moscow: Alpina Business Books. Ded I. (2015). Model consolidated financial statements reporting. PWC.

Eganyan, A. (2017). Infrastructure investments: Money, projects, interests. PPP, concessions, project financing. Moscow: Alpina Publisher.

Efimova, O. V. (2015). Financial analysis for making economic decisions: a textbook. 2nd ed. Moscow: Omega-L.

Eskindarov, M. A., Fedotova, M. A. (2015). Business valuation: a textbook. Moscow: Knorus.

Higgins, R. S. (2013). Financial management: capital and investment management. Moscow: I.D. Williams.

Higgins, R. S. (2010). Financial analysis: tools for making business decisions. Moscow: I.D. Williams.

Ivashkovskaya, I. V., Stepanova, A. N., Kokoreva, M. S. (2016). Financial architecture of companies. Comparative studies in developed and emerging markets: Monograph. Moscow: INFRA-M.

Copeland, T., Koller, T., Murrin, J. (2012). The Cost of Companies: Evaluation and Management. 3rd ed. Moscow: Olimp-Business.

Kutuzov, A. S. (2014). Document templates for project management. Moscow: BINOM.

Limitovsky, M.A., Lobanova, E.N. (2018). Financial management as a sphere of applied use of corporate finance. Part 1. Applied Corporate Finance. Moscow: President University of the Russian Federation.

Limitovsky, M. A., Lobanova, E. N. (2018). Financial management as a sphere of applied use of corporate finance. Part 2. Modern financial management. Moscow: President University of the Russian Federation. 
Limitovsky, M. A. (2018). Investment projects and real options in emerging markets: studies. manual for bachelors and graduate. Moscow: Publishing Yurayt.

Lipsits, I. V., Kosov, V. V. (2016). Investment analysis. Preparation and evaluation of investments in real assets: Textbook. Moscow: Infra-M.

Lobanova, E. N. (2015). Corporate financial management: practical training. Benefit. / M .: Publishing Yurayt. Lukasevich, I. Ya. (2012). Investments. Moscow: Infra-M.

Lukasevich, I. Ya. (2015). Financial management. 3rd ed. Moscow: Publishing House "National Education”.

Nezamakin, V. N. (2014). Financial Management: Textbook for Bachelor. Moscow: Yurayt.

Nikonov, I. A. (2016). Project analysis and project financing. Moscow: Alpina Publisher.

Popov, G. P. (2015). How companies become a first-class borrower. Moscow: Knorus.

Proctor, K. Scott. (2013). Building financial models with Excel: A guide for professionals. 2ed ed.

Rogova, E. M. (2015). Financial management. Moscow: Publishing Yurayt.

Rosenbaum, J., Pearl, J. (2015). Investment Banking. Wiley Finance.

Salin, V. N., Shpakovskaya E.P. (2015). Statistics: A tutorial. 2nd ed. Moscow: Knorus.

Sincley, D. (2008). Financial management in a commercial bank and in the financial services industry. Moscow: Alpina Business Books.

Sharp, U., Alexander G. (2009). Investments. Moscow: Infra-M.

Shokhin, E. I. (2015). Corporate Finance: a textbook. Moscow: Knorus.

Teplova, T. V. (2017). Corporate Finance: a textbook for bachelors. Moscow: Yurayt.

Teplova, T. V. (2017). Investments: A textbook for bachelors. Moscow: Yurayt.

Teplova, T. V., Berzon, N. I. (2017). Innovation in financial markets. Moscow: Higher School of Economics.

Корпоративный банкинг: анализ, оценка и структура финансирования компании

\section{Дарья Гребенькова}

Факультет международных финансов, Департамент мировой экономики и мировых финансов, Финансовый университет, Москва, Россия

Аннотация. Сегодня, в период продолжающихся изменений на финансовом рынке, банки сталкиваются с проблемами снижения издержек, пересмотра продуктовой линейки и более четкой сегментации клиентов. В среде корпоративных клиентов также наблюдаются существенные изменения: происходит ротация кадров, меняются стратегии развития компаний, что влечет за собой новые требования к банковским продуктам. Могут ли банки быстро адаптироваться к новым рыночным условиям и оптимизировать работу с корпоративными клиентами, используя существующие технологии и информационные системы? Как организавать корпоративные продажи банковских продуктов в текущих условиях? На эти вопросы автор пытается ответить в своей статье. Статистический материал собран автором в ходе собственных исследований.

Ключевые слова: корпоративный банкинг; банковские продукты; стратегические цели банка; корпоративные клиенты банковских услуг 
Appendix

Table 1

The average price for March-April in Nizhny Novgorod in the rental market of commercial premises in the district division, $\left(R \cup B / m^{2}\right)$

\begin{tabular}{lcccc}
\hline \multirow{2}{*}{ Area } & $\begin{array}{c}\text { Average demand } \\
\text { price }\end{array}$ & $\begin{array}{c}\text { Average demand } \\
\text { price }\end{array}$ & $\begin{array}{c}\text { Change + } \\
\text { in natural terms, }\end{array}$ & \multirow{2}{*}{ Change in \% } \\
\cline { 2 - 3 } & March & April & RUB/sq.M & \\
\cline { 2 - 3 } & RUB./sq.M & RUB./sq.M & RUn & -1.3 \\
\cline { 2 - 4 } Autozavodsky & 725 & 715.5 & -9.5 & -2.1 \\
Kanavinsky & 655.5 & 641.8 & -13.7 & 3.1 \\
Leninsky & 687.9 & 709.2 & 21.3 & 2.9 \\
Moskovsky & 550.5 & 566.3 & 15.8 & 2.3 \\
Nizhegorodsky & 781.5 & 799.4 & 17.9 & 2.7 \\
Prioksky & 689.9 & 708.7 & 18.8 & 1.5 \\
Sovetsky & 700 & 710.6 & 10.6 & 3.3 \\
\hline Sormovsky & 724.2 & 748 & 23.8 & \\
\hline
\end{tabular}

Source: The author.

Table 2

Competitive environment of the Lotus Plaza project

\begin{tabular}{ccccc}
\hline Name & GBA, sq. $\mathbf{m}$. & GLA, sq. $\mathbf{m}$. & Project status & Start date \\
\hline Sky & 131,000 & 68,000 & Exist/work & 2015 \\
Olimp & 19,800 & 16,700 & Exist/work & 2015 \\
Fire-Bird & 84,000 & 59,000 & Exist/work & 2015 \\
Cremea & 42,000 & 22,000 & Exist/work & 2015 \\
\hline
\end{tabular}

Source: The author.

Table 3

Brief description of the client's application for investment project financing

\begin{tabular}{lc}
\hline \multicolumn{1}{c}{ Criteria } & Description \\
\hline Aim & $\begin{array}{r}\text { Refinancing of debt to another Bank for the construction of an } \\
\text { additional building of the Mall } \\
\text { Financing of current activities }\end{array}$ \\
$\begin{array}{l}\text { Financing of the investment program (additional 10,000 sq.M.) } \\
\text { Time-line } \\
\text { Loan an interest payments } 1,500,000,000 \\
\text { Regress }\end{array}$ & $\begin{array}{c}10 \text { years } \\
\text { Quarterly accrual }\end{array}$ \\
\hline
\end{tabular}

Source: The author based on the data received from the client. 
Table 4

Express assessment of the balance sheet of the group of companies based on good balance

\begin{tabular}{|c|c|c|c|}
\hline & Conditions & 01.01 .2018 & 01.10 .2018 \\
\hline \multirow{6}{*}{$\begin{array}{l}\text { Good balance } \\
\text { signs }\end{array}$} & Growth of balance sheet & $\mathrm{v}$ & $\mathrm{v}$ \\
\hline & Growth current assets > Growth non -current assets & $\mathrm{V}$ & $x$ \\
\hline & Equity > Loans; Growth Equity> Growth Loans & $\mathrm{V}$ & $x$ \\
\hline & Growth receivables $=$ Growth payables & $\mathrm{v}$ & $x$ \\
\hline & Share of working capital >10\% & $\mathrm{x}$ & $\mathrm{x}$ \\
\hline & No item uncovered loss & $\mathrm{v}$ & $\mathrm{v}$ \\
\hline & $v$-condition is met; $x$-condition is not & & \\
\hline
\end{tabular}

Source: The author based on the financial analysis of the financial statements of the client.

Table 5

The ratio of net assets

\section{Condition}

Comparison of Net assets and company's authorized capital
01.10.2017

Net assets > Capital
01.01.2018

01.10 .2018

Source: The author based on the financial analysis of the financial statements of the client.

Table 6

Correlation of groups of assets and liabilities to the solvency of the Group of companies

\begin{tabular}{cccc}
\hline Criteria & $\mathbf{0 1 . 1 0 . 2 0 1 7}$ & $\mathbf{0 1 . 0 1 . 2 0 1 8}$ & $\mathbf{0 1 . 1 0 . 2 0 1 8}$ \\
\hline $\mathrm{A}_{1}>\Pi_{1}$ & done & done & done \\
$\mathrm{A}_{2}>\Pi_{2}$ & done & done & done \\
$\mathrm{A}_{3}>\Pi_{3}$ & none & none & none \\
$\mathrm{A}_{4}<\Pi_{4}$ & none & none & none
\end{tabular}

Source: The author based on the financial analysis of the financial statements of the client.

Table 7

Compliance with current liquidity ratios

\begin{tabular}{cccc}
\hline Criteria & $\mathbf{0 1 . 1 0 . 2 0 1 7}$ & $\mathbf{0 1 . 0 1 . 2 0 1 8}$ & $\mathbf{0 1 . 1 0 . 2 0 1 8}$ \\
\hline$(\mathrm{A} 1+\mathrm{A} 2)$ & $1,547,736$ & $1,627,106$ & $1,624,821$ \\
$(\Pi 1+\Pi 2)$ & 113,567 & 126,147 & 378,240 \\
$\mathrm{~A}>\Pi$ & done & done & done \\
\hline
\end{tabular}

Source: The author, on the basis of the financial analysis of the financial statements of the client. 
Table 8

The functional approach to the analysis of balance sheet liquidity

\begin{tabular}{|c|c|c|c|c|c|c|}
\hline Criteria & 01.10.2017 & $\begin{array}{l}\text { Surplus/ } \\
\text { Deficit }\end{array}$ & 01.01.2018 & $\begin{array}{l}\text { Surplus/ } \\
\text { Deficit }\end{array}$ & 01.10.2017 & $\begin{array}{l}\text { Surplus/ } \\
\text { Deficit }\end{array}$ \\
\hline A4<ா3+П4 & done & $1,437,556$ & done & $1,506,468$ & done & $1,251,902$ \\
\hline$A 3>\sqcap 1$ & none & $-110,180$ & none & $-120,638$ & none & $-195,439$ \\
\hline $\mathrm{A} 2+\mathrm{A} 1>\Pi 1$ & done & $1,547,736$ & done & $1,627,106$ & done & $1,447,341$ \\
\hline
\end{tabular}

Source: The author, based on the financial analysis of the financial statements of the client.

Table 9

Seven main liquidity ratios of the balance sheet

\begin{tabular}{|c|c|c|c|c|}
\hline Coefficient & 01.10 .2017 & 01.01 .2018 & 01.10 .2018 & Normative \\
\hline Total solvency & 0.64 & 0.71 & 0.68 & $>1$ \\
\hline Absolute liquidity & 9.82 & 8.82 & 2.939 & $0.2-0.7$ \\
\hline Critical evaluation & 13.63 & 12.90 & 4.30 & $0.7-0.8$ \\
\hline Current liquidity & 13.66 & 12.94 & 4.31 & $\begin{array}{l}\text { 1.5. but better } \\
2.0-3.5\end{array}$ \\
\hline Maneuverability of operating capital & 0.00 & 0.00 & 0.00 & Must decrease \\
\hline Share of working capital in assets & 0.18 & 0.19 & 0.16 & $>0.5$ \\
\hline $\begin{array}{l}\text { Current assets security in working } \\
\text { capital }\end{array}$ & -3.33 & -2.76 & -2.77 & $>0.1$ \\
\hline
\end{tabular}

Source: The author, based on the financial analysis of the financial statements of the client.

Table 10

Five key financial stability ratios on the balance sheet

\begin{tabular}{lcccc}
\hline \multicolumn{1}{c}{ Coefficient } & $\mathbf{0 1 . 1 0 . 2 0 1 7}$ & $\mathbf{0 1 . 0 1 . 2 0 1 8}$ & $\mathbf{0 1 . 1 0 . 2 0 1 8}$ & Base \\
\hline Capitalization & 3.86 & 2.36 & 1.57 & Not higher 1.5 \\
Security of current assets with own funds & -3.33 & -2.76 & -2.77 & 0.39 \\
Financial independence & & 0.30 & 0.6 \\
Financing ratio & 0.21 & 0.42 & 0.64 & $>0.7$ \\
Financial stability & 0.26 & 0.99 & 0.96 & $>0.6$ \\
\hline
\end{tabular}

Source: The author, based on the financial analysis of the financial statements of the client. 
Table 11

Analysis of the adequacy of sources of funding for the formation of stocks

\begin{tabular}{lccc}
\hline \multicolumn{1}{c}{ Coefficient } & $\mathbf{0 1 . 1 0 . 2 0 1 7}$ & $\mathbf{0 1 . 0 1 . 2 0 1 8}$ & $\mathbf{0 1 . 1 0 . 2 0 1 8}$ \\
\hline Inventory & 3387 & 5509 & 5321 \\
Working capital & $-5,167,933$ & $-4,499,021$ & $-4,516,587$ \\
Functional capital & $1,437,556$ & $1,506,468$ & $1,251,902$ \\
Total major sources of funding & $1,551,123$ & $1,632,615$ & $1,630,142$ \\
Financial stability (own) & $-5,164,546$ & $-4,493,512$ & $-4,511,266$ \\
Financial stability (current) & $1,434,169$ & $1,500,959$ & $1,246,581$ \\
Financial stability (total) & $1,547,736$ & $1,627,106$ & $1,624,821$ \\
Overall assessment of the adequacy & $0 ; 1 ; 1$ & $0 ; 1 ; 1$ & $0 ; 1 ; 1$ \\
\hline
\end{tabular}

Source: The author, based on the financial analysis of the financial statements of the client.

Table 12

Score assessment of financial stability based on the boundary classes of the balance sheet

\begin{tabular}{lccc}
\hline \multicolumn{1}{c}{ Criteria } & $\mathbf{0 1 . 1 0 . 2 0 1 7}$ & $\mathbf{0 1 . 0 1 . 2 0 1 8}$ & $\mathbf{0 1 . 1 0 . 2 0 1 8}$ \\
\hline Absolute liquidity & 14 & 14 & 14 \\
Critical assessment & 11 & 11 & 11 \\
Current liquidity & 20 & 20 & 20 \\
The share of working capital in assets & 0 & 0 & 0 \\
Current assets security & 0 & 0 & 0 \\
Capitalization & 0 & 0 & 0 \\
Financial independence / autonomy & 1 & 1 & 1 \\
Financial stability & 5 & 5 & 5 \\
Final grade & 51 & 51 & 51 \\
\hline
\end{tabular}

Source: The author, on the basis of the financial analysis of the financial statements of the client.

Table 13

Calculation of profitability indicators of the Group

\begin{tabular}{cccc}
\hline Indicator & $\mathbf{0 1 . 1 0 . 2 0 1 7}$ & $\mathbf{0 1 . 0 1 . 2 0 1 8}$ & $\mathbf{0 1 . 1 0 . 2 0 1 8}$ \\
\hline Return on sales & 0.72 & 0.98 & 0.97 \\
Accounting profitability by ordinary activity & 0.55 & 0.49 & 0.40 \\
Net profitability & 0.35 & 0.35 & 0.25 \\
Return on assets & 0.09 & 0.10 & 0.10 \\
Equity profitability & 0.34 & 0.30 & 0.27 \\
Gross margin & 0.97 & 0.98 & 0.97 \\
Cost performance & 26.10 & 35.82 & 21.38 \\
Return on permanent capital & 0.09 & 0.11 & 0.11 \\
Economic growth stability ratio & 0.34 & 0.30 & 0.27 \\
Modeling ROA, where & 0.09 & 0.10 & 0.10 \\
d1 & 0.24 & 0.29 & 0.42 \\
R3 & 0.35 & 0.35 & 0.25 \\
\hline
\end{tabular}

Source: The author, based on the financial analysis of the financial statements of the client. 
Table 14

General Group Turnover Indicators

\begin{tabular}{lccc}
\hline \multicolumn{1}{c}{ Indicator } & $\mathbf{0 1 . 1 0 . 2 0 1 7}$ & $\mathbf{0 1 . 0 1 . 2 0 1 8}$ & $\mathbf{0 1 . 1 0 . 2 0 1 8}$ \\
\hline Resource performance & 0.24 & 0.29 & 0.42 \\
Mobile asset turnover & 1.31 & 1.69 & 2.62 \\
Capital productivity & 0.30 & 0.36 & 0.51 \\
Return on equity & 0.96 & 0.84 & 1.09 \\
\hline
\end{tabular}

Source: The author, based on the financial analysis of the financial statements of the client.

Table 15

Baseline and Stressed DSCR Indicator by Customer Model

\begin{tabular}{ccccccccccc}
\hline DSCR base & 0.96 & 1.10 & 1.26 & 1.46 & 1.69 & 1.99 & 2.41 & 3.01 & 4.08 & 6.85 \\
DSCR stressed & 0.92 & 1.05 & 1.19 & 1.37 & 1.56 & 1.83 & 2.18 & 2.70 & 3.62 & 6.02 \\
\hline
\end{tabular}

Source: The author, based on the financial analysis of the financial statements of the client.

Table 16

New and final terms of project financing

\begin{tabular}{cc}
\hline Aim & $\begin{array}{c}\text { Refinancing of debt to another Bank for the construction of an } \\
\text { additional shopping center mall } \\
\text { Financing of current activities }\end{array}$ \\
\hline Amount & Financing of the investment program: construction of 10 000 sq.m \\
Term & RUB 1,200,000,000 \\
Credit rate with & 10 yaers \\
Interest and loan payments & $11.8 \%$ \\
Possibility of recourse & Quarterly accrual \\
\hline
\end{tabular}

Source: The author, based on the developed financial model.

Table 17

Cumulative Cash Flow for Credit Analysis

\begin{tabular}{cc}
\hline Indicator & Amount (RUB) \\
\hline EBITDA 12M. & $25,365,376$ \\
DEBT & $8,877,000$ \\
DEBT/EBITDA & 3.60 \\
INTEREST 12M. & $1,046,160$ \\
CFADS based EBITDA & $20,852,301$ \\
DEBT+INTEREST (LOAN PORTFOLIO) & $9,923,160$
\end{tabular}

Source: The author, based on the developed financial model. 
Table 18

Calculation of the score of a borrower according to the method of MSP-Bank for the Group

\begin{tabular}{|c|c|c|c|}
\hline \multicolumn{4}{|c|}{ Quantitative characteristics } \\
\hline Factor & Indicator & & Mark/Point \\
\hline Capital adequacy ratio (autonomy ratio) & 0.39 & & 10 \\
\hline Total liquidity ratio & 2.94 & & 10 \\
\hline Net profit margin & 0.25 & & 5 \\
\hline Final calculation & & 8,75 & \\
\hline \multicolumn{4}{|c|}{ Qualitative characteristics } \\
\hline Factor & \multicolumn{3}{|c|}{ Mark/Point } \\
\hline The period of the company & \multicolumn{3}{|c|}{10} \\
\hline Experience and qualifications & \multicolumn{3}{|c|}{10} \\
\hline Final calculation & \multicolumn{3}{|c|}{10} \\
\hline
\end{tabular}

Source: The author, based on the PJSC MSP-Bank credit rating methodology.

Table 19

Calculation of additional financial covenants by bank model

\begin{tabular}{|c|c|c|c|c|c|c|c|c|c|c|c|}
\hline Time-Line & 2018 & 2019 & 2020 & 2021 & 2022 & 2023 & 2024 & 2025 & 2026 & 2027 & 2028 \\
\hline $\begin{array}{l}\text { The present } \\
\text { value of CFADS } \\
\text { for EBITDA, } \\
\text { (RUB) }\end{array}$ & $1,777,535$ & $1,701,286$ & $1,621,210$ & $1,456,802$ & $1,308,450$ & $1,255,050$ & $1,127,649$ & $1,012,954$ & 909,909 & 820,791 & $12,991,636$ \\
\hline $\begin{array}{l}\text { Present Value } \\
\text { CFADS CF, (RUB) }\end{array}$ & 809,489 & $1,894,080$ & $1,780,648$ & $1,592,708$ & $1,424,605$ & $1,348,507$ & $1,206,178$ & $1,078,871$ & 965,001 & 863,149 & $12,963,236$ \\
\hline $\begin{array}{l}\text { LLCR (by } \\
\text { EBITDA), (RUB) }\end{array}$ & 10.48 & 9.79 & 9.10 & 8.26 & 7.53 & 6.84 & 5.96 & 4.99 & 4.94 & - & 4.94 \\
\hline LLCR (CF) (RUB) & 10.45 & 10.61 & 9.82 & 8.88 & 8.05 & 7.28 & 6.33 & 5.29 & 5.22 & - & 5.22 \\
\hline
\end{tabular}

Source: The author, based on the developed financial model.

Table 20

Calculation of additional financial covenants for the bank stress model

\begin{tabular}{|c|c|c|c|c|c|c|c|c|c|c|c|}
\hline Time-Line & 2018 & 2019 & 2020 & 2021 & 2022 & 2023 & 2024 & 2025 & 2026 & 2027 & 2028 \\
\hline $\begin{array}{c}\text { The present value } \\
\text { of CFADS for } \\
\text { EBITDA (RUB) }\end{array}$ & $1,427,304$ & $1,368,440$ & $1,305,982$ & $1,174,845$ & $1,056,253$ & $1,014,433$ & 912,427 & 820,448 & 737,721 & 666,777 & $10,484,631$ \\
\hline $\begin{array}{l}\text { Present Value } \\
\text { CFADS CF(RUB) }\end{array}$ & 470,195 & $1,571,630$ & $1,475,265$ & $1,319,557$ & $1,180,284$ & $1,115,404$ & 997,678 & 892,377 & 798,191 & 713,945 & $10,534,524$ \\
\hline $\begin{array}{c}\text { LLCR (by EBITDA) } \\
\text { (RUB) }\end{array}$ & 8.46 & 7.91 & 7.36 & 6.68 & 6.09 & 5.54 & 4.83 & 4.05 & 4.01 & - & 4.01 \\
\hline LLCR (CF) (RUB) & 8.50 & 8.79 & 8.13 & 7.35 & 6.66 & 6.02 & 5.23 & 4.37 & 4.32 & - & 4.32 \\
\hline
\end{tabular}

Source: The author, based on the developed financial model. 
Table 21

Group bankruptcy analysis by Altman two-factor model.

\begin{tabular}{|c|c|c|c|c|}
\hline Indicator & Name & 01.10 .2017 & 01.01.2018 & 01.10 .2018 \\
\hline \multicolumn{5}{|c|}{ 1. Altman two-factor model } \\
\hline $\begin{array}{l}\text { Current liquidity } \\
\text { ratio }\end{array}$ & CR & 13.66 & 12.94 & 4.31 \\
\hline Borrowed capital & $B C$ & $6,719,056$ & $6,131,636$ & $6,146,729$ \\
\hline Liabilities & L & $8,457,565$ & $8,734,339$ & $10,072,121$ \\
\hline Z-score & - & -15.00516606 & -14.24175923 & -4.979375776 \\
\hline \multicolumn{5}{|c|}{ The probability of bankruptcy of the enterprise } \\
\hline \multicolumn{5}{|c|}{$\begin{array}{c}- \text { if } Z=0-\text { approximately equal to } 50 \% \\
\text { - if } Z<0 \text { - less than } 50 \% \text {, and decreases with decreasing } Z \\
\text { - if } Z>0 \text { - more than } 50 \% \text {, and increases with increasing } \\
\text { Often contradicts the } 5 \text {-factor method }\end{array}$} \\
\hline $\begin{array}{c}\text { The probability of } \\
\text { bankruptcy }\end{array}$ & - & less than $50 \%$ & less than $50 \%$ & less than $50 \%$ \\
\hline
\end{tabular}

Source: The author, based on a model for assessing bankruptcy by Altman.

Table 22

Calculation of the change in the CFADS Group in the event of a change in the inflation rate

\begin{tabular}{|c|c|c|c|c|c|c|c|}
\hline \multicolumn{8}{|c|}{ Inflation } \\
\hline Indicator & Amount & 0,02 & 0,04 & 0,06 & 0,08 & 0,1 & 0,12 \\
\hline CFADS & $20,852,301$ & $20,868,554$ & $20,884,808$ & $20,901,061$ & $20,917,314$ & $20,933,567$ & $20,949,821$ \\
\hline $\begin{array}{l}\text { Source: The } \\
\text { Table } 23 \\
\text { Averaged co }\end{array}$ & $\begin{array}{l}\text { uthor, based on } \\
\text { culation of the }\end{array}$ & $\begin{array}{l}\text { the developed } \\
\text { change in the }\end{array}$ & $\begin{array}{l}\text { financial model. } \\
\text { Group's DSCR ir }\end{array}$ & the event of $c$ & hange in CFA & & \\
\hline \multicolumn{2}{|c|}{ Loan portfolio } & $9,923,160$ & $9,923,160$ & $9,923,160$ & $9,923,160$ & $9,923,160$ & $9,923,160$ \\
\hline \multicolumn{2}{|c|}{ DSCR } & 2.103 & 2.105 & 2.106 & 2.108 & 2.110 & 2.111 \\
\hline
\end{tabular}

Source: The author, based on the developed financial model.

Table 24

Calculation of the change in CFADS of the Group in case of a change in the rental rate indicator

\begin{tabular}{cccccccc}
\hline \multicolumn{1}{c}{ Rental rate } \\
\hline \multirow{2}{*}{ Indicator } & Amount & -0.02 & -0.04 & -0.06 & -0.08 & -0.1 & -0.12 \\
& & & & & & & \\
CFADS & $20,852,301$ & $20,839,993$ & $20,827,684$ & $20,815,376$ & $20,803,068$ & $20,790,760$ & $20,778,451$ \\
\hline
\end{tabular}

Source: The author, based on the developed financial model. 
Table 25

Averaged calculation of the change in the Group's DSCR in the event of a change in the CFADS indicator

\begin{tabular}{ccccccc}
\hline Loan portfolio & $9,923,160$ & $9,923,160$ & $9,923,160$ & $9,923,160$ & $9,923,160$ & $9,923,160$ \\
DSCR & 2.10 & 2.10 & 2.10 & 2.10 & 2.10 & 2.09 \\
\hline
\end{tabular}

Source: The author, based on the developed financial model.

Table 26

Calculation of the change in CFADS of the Group in case of a change in the indicator of operating costs

\begin{tabular}{|c|c|c|c|c|c|c|c|}
\hline \multicolumn{8}{|c|}{ OPEX } \\
\hline Indicator & Amount & $2 \%$ & $4 \%$ & $6 \%$ & $8 \%$ & $10 \%$ & $12 \%$ \\
\hline CFADS & $20,852,301$ & $20,685,507$ & $20,518,713$ & $20,351,918$ & $20,185,124$ & $20,018,330$ & $19,851,536$ \\
\hline \multicolumn{8}{|c|}{ Source: The author, based on the developed financial model. } \\
\hline \multicolumn{8}{|l|}{ Table 27} \\
\hline \multicolumn{8}{|c|}{ Averaged calculation of the change in the Group's DSCR in the event of a change in CFADS } \\
\hline \multicolumn{2}{|c|}{ Loan portfolio } & $9,923,160$ & $9,923,160$ & $9,923,160$ & $9,923,160$ & $9,923,160$ & $9,923,160$ \\
\hline \multicolumn{2}{|c|}{ DSCR } & 2,085 & 2,068 & 2,051 & 2,034 & 2,017 & 2,001 \\
\hline
\end{tabular}

Source: The author, based on the developed financial model.

Table 28

Calculation of the change in the CFADS Group in the event of a change in the load factor of the rentable area

\begin{tabular}{ccccccccc}
\hline \multicolumn{10}{c}{$\%$ Space occupancy } \\
\hline Indicator & Amount & $-2 \%$ & $-4 \%$ & $-6 \%$ & $-8 \%$ & $-10 \%$ & $-12 \%$ \\
CFADS & $20,852,301$ & $20,429,716$ & $20,007,132$ & $19,584,547$ & $19,161,963$ & $18,739,378$ & $18,316,794$ \\
\hline
\end{tabular}

Source: The author, based on the developed financial model.

Table 29

Averaged calculation of the change in the Group's DSCR in the event of a change in the CFADS indicator

\begin{tabular}{ccccccc}
\hline Loan portfolio & $9,923,160$ & $9,923,160$ & $9,923,160$ & $9,923,160$ & $9,923,160$ & $9,923,160$ \\
DSCR & 2.06 & 2.02 & 1.97 & 1.93 & 1.89 & 1.85 \\
\hline
\end{tabular}

Source: The author, based on the developed financial model.

Table 30

Estimated indicator of debt coverage ratio to the bank

\begin{tabular}{lcccccccccc}
\hline & 2018 & 2019 & 2020 & 2021 & 2022 & 2023 & 2024 & 2025 & 2026 & 2027 \\
DSCR Bank's Model & 1.19 & 1.37 & 1.58 & 1.74 & 1.91 & 2.29 & 2.63 & 3.04 & 3.61 & 5.72 \\
\hline
\end{tabular}

Source: The author, based on the developed financial model. 
Table 31

The final description of the client by the method $6 \mathrm{C}$

\begin{tabular}{|c|c|}
\hline Criteria & Description \\
\hline Character & $\begin{array}{l}\text { Reliable borrower, bank customer for over } 5 \text { years } \\
\text { Works on the real estate market in Nizhny Novgorod for over } 10 \text { years } \\
\text { Market share is estimated at } 20-23 \%\end{array}$ \\
\hline Capacity & $\begin{array}{l}\mathrm{B++} \\
\text { The client is solvent, but abrupt changes in economic indicators can significantly } \\
\text { worsen the payments on the debt; a special control is applied, which allowed to } \\
\text { increase the rating from B to B++ (see Control) }\end{array}$ \\
\hline Capital/currency & $\begin{array}{l}\text { Cash flows are stable in the absence of abrupt economic changes in the country. } \\
\text { Balance currency on the last reporting date } 10 \text { billion roubles } \\
\text { Cash flows in the GC do not have a complex structure of redistribution }\end{array}$ \\
\hline Collateral & $\begin{array}{l}\text { The building of a shopping and entertainment center with a total cost for the } \\
\text { appraisal of an appraiser from a report provided by a client of 2,000,000 thousand } \\
\text { rubles }\end{array}$ \\
\hline Conditions & $\begin{array}{l}1,200,000 \text { thousand roubles. } \\
10 \text { years } \\
11.8 \% \\
\text { Quarterly accrual } \\
\text { Lack of Balloon-payment }\end{array}$ \\
\hline Control & $\begin{array}{l}\text { A number of covenants of a security, general and financial nature have been } \\
\text { established after analyzing the initial and stressed model }\end{array}$ \\
\hline
\end{tabular}

Source: The author, based on a final analysis of the feasibility of a credit transaction according to Method 6 C. 